\title{
Wolston Park Hospital, 1865-2001: A Retrospect
}

\author{
Mark Finnane
}

We know about the first day at Wolston Park from a report in the Brisbane Courier of 1865 . On 12 January of that year, seven prison warders (two of them women) and ten police constables escorted 57 male and twelve female lunatics from Brisbane Gaol 'to the new Asylum at Woogaroo'. Since 1859, Queensland's insane had no longer been sent to Sydney, but were lodged instead at the Brisbane Gaol. Now the asylum was ready, its residents were loaded into cabs and taken down to the river. There they boarded a steamer named Settler and were conveyed down the river to the landing point near Woogaroo Creek. The name of the asylum hinted at the reality that this was Aboriginal land: the word Woogaroo, so it was remembered in the 1930s, being a corruption of an Aboriginal word meaning 'to step over a person lying down'. ${ }^{1}$ Aboriginal people would be among the earliest inhabitants of the asylum, but not in great numbers. Instead, the institution was rapidly filled from its earliest days with the immigrant settlers who made up most of the colony's growing population.

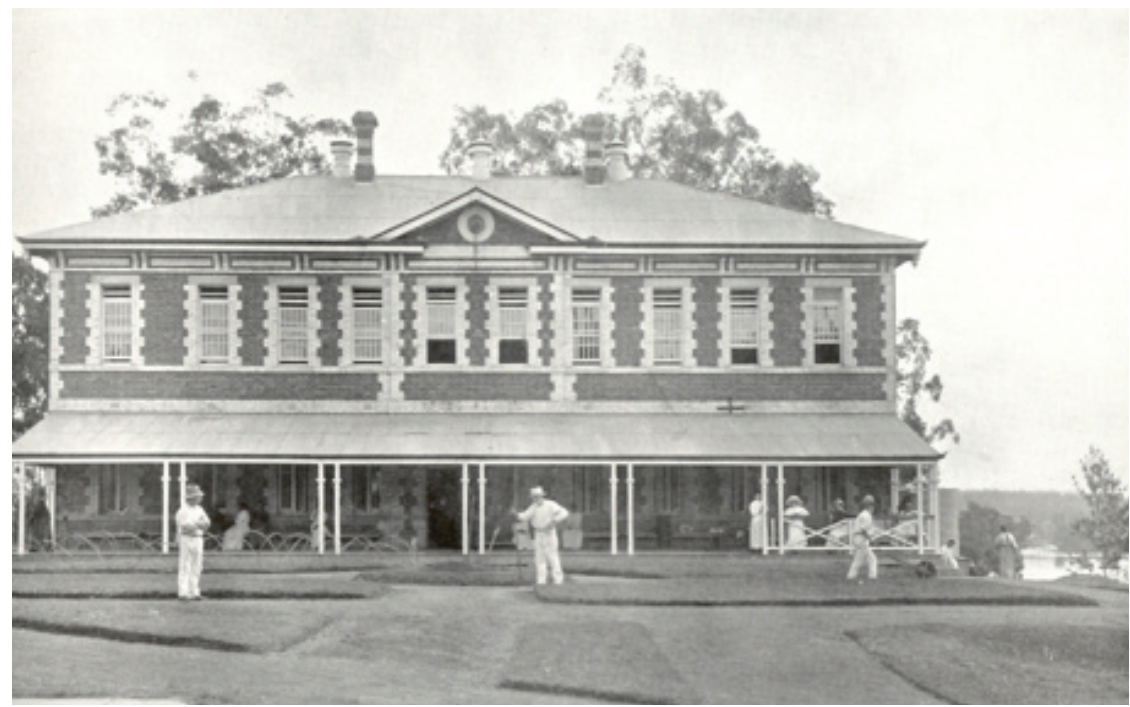

Figure 1: Wolston Park 
They were people like Eliza Gorman, a young Irish woman who had been committed as a lunatic from the South Brisbane immigration depot in February 1864. Fellow passengers on her ship said she had been placed under restraint on the ship that brought her to Australia for her 'exceedingly violent behaviour'. The warden at the depot gave similar evidence, and Eliza was committed. She was among the group brought down to the new asylum, but she died the following day. The cause of death was said to be 'gradual decay', but she was described as having been in a state of 'profound melancholy when admitted'. ${ }^{2}$ Her fate was unusual - many of the female inmates appear to have recovered quickly and then been discharged, at least in these early days. By contrast, at least 45 of the 57 males first brought to the new asylum were still there two years later, when an inquiry was held. They were all immigrants, from the many countries that fed the colonial population, but especially from Ireland, England, Germany, Scotland and China.

The history of Wolston Park Hospital is almost coincident with the history of Queensland itself. ${ }^{3}$ To know how much has changed since its first days, consider an inquiry from the Colonial Office to the Governor of Queensland and all other colonies of the British Empire in 1864. This requested information on the state of the hospitals and asylums of the colony, following a scandal over the state of the hospitals in Jamaica. ${ }^{4}$ Queensland was part of the British Empire, and its government was answerable to London. Its institutions were to be shaped by imperial expectations as well as local conditions. By August 1864, Governor Bowen reported to the Colonial Office that the local parliament had voted funds to establish 'a general lunatic asylum, which has been built on the best model procurable here, and is surrounded with nearly two hundred acres of gardens for the use and amusement of the inmates'. ${ }^{5}$ There was some hyperbole in the claim - for many years to come, the gardens would be no more than an aspiration.

The earliest buildings separated male and female patients by some distance, with the superintendent's quarters in between. The male division was located at the south-west end of the site, near Woogaroo Creek; the female division was further up the hill, where the oldest, long-abandoned building still stands. As one flood after another took its toll, and the population doubled and trebled, new buildings advanced northwards up the slope. Major additions to the site came during the three decades after 1909 when successive wards around the recreation oval were added, all of them to remain in use until the end of the twentieth century. ${ }^{6}$

These were years of very substantial capital expenditure at Goodna, at a time when the Queensland Labor government was in advance of Australia in its commitment to the development of public medical services. A further expansion of the buildings took place from the 1960s, this time moving east of the old hospital as Ellerton House and the Barrett Centre were added. Today, following the construction of a new mental health centre at the easternmost part of the land originally set aside in the 1860 s, we can still see in a quite striking way the evolution of a site that has developed incrementally across the grounds rather than in layers on the one area. 


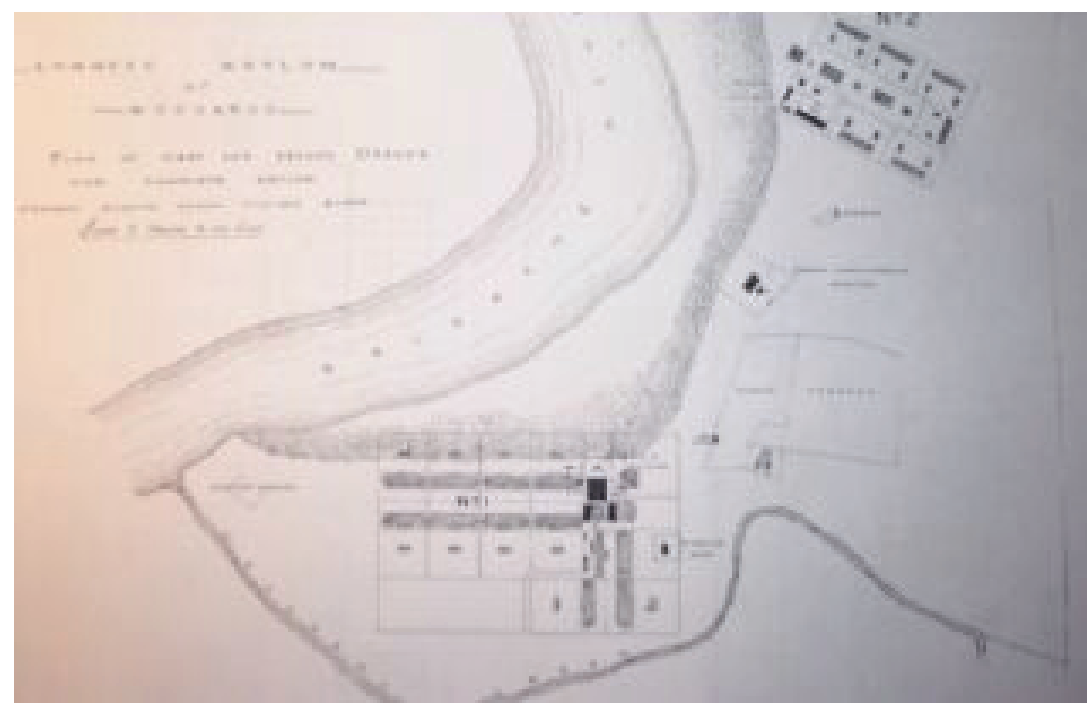

Figure 2: Asylum by the river — the vision in 1869

The Woogaroo Asylum was not only constantly relocated - it was endlessly renamed. Every generation wanted to put its own stamp on the site and its functions. The renaming reflected both changing fashions in psychiatric care and a desire to escape the stigma associated with an institution for the insane. So Woogaroo quietly became Goodna Asylum for the Insane some time in 1880, perhaps to allow its reputation to regenerate in the wake of four official inquiries into Woogaroo after 1867. In 1898, it appears as the Goodna Hospital for the Insane, the name for the next 40 years, until it became the Brisbane Mental Hospital about 1940. We know much more about this change since it was so purposeful. Under the youthful influence of the new medical superintendent Basil Stafford, and with the strong support of the Labor Minister for Health Ned Hanlon, Queensland reviewed its legalisation and administration, abolishing the terms 'insane', 'insanity' and 'asylum', and re-establishing a network of mental hospitals within a department of 'Mental Hygiene'.

It was Stafford again, under a new political order though with an equally supportive minister, H.W. Noble - himself a doctor - who oversaw the next name change, to Brisbane Special Hospital in 1963. The Mental Health Act of 1962 registered a new emphasis on integration of psychiatric with other health services. The title of 'Special Hospital' appeared to designate the specialised service being provided at places like the Wolston Park facility, which no longer bore an exclusive responsibility for mental illness - the mentally ill were now also to be treated in general hospitals, while the senile aged were rehoused in separate 'Eventide' homes. In the late 1960s, the hospital was renamed yet again, as the integration of psychiatric facilities, and especially their development into community-based services, diminished the focus on regional hospitals - by 1970, the hospitals of the Psychiatric Services Division were no longer Brisbane, 
Ipswich, Toowoomba and Charters Towers, but Wolston Park, Challinor, Baillie Henderson and Mosman Hall.

The endless renaming did not go unremarked. In 1938, Minister Hanlon was challenged by the Member for West Moreton to justify his proposals to replace 'insanity' with 'mental hygiene', for 'a rose by any other name would smell just as sweet, and I suppose a thorn by any other name would leave just as deep a prick in the flesh. It does not matter what name is bestowed on these things, it is the condition that counts.' ${ }^{7}$ It was the kind of challenge that went back to the very beginnings of the institution. In reality, the Woogaroo Asylum was established in a vacuum. It was the kind of institution a colony was expected to have, but how would it be managed? The colonial government told London in 1864 that any deficiencies in hospitals and asylums of the colonies should not be attributed 'to any wilful neglect on the part of the Legislative and Executive authorities, but rather to the unavoidable want of adequate knowledge of what such Institutions ought to be, and of the methods by which the improvements of modern Science are to be introduced'. 8

By looking at some of the factors that have shaped the history of Wolston Park, we can better understand the changes since those early days in 'knowledge of what such institutions ought to be'. ${ }^{9}$ In this short historical overview, we look first at the history of the site, second at the changing policy contexts that shaped the functions and population of the hospitals, and third at some characteristics of the changing populations themselves. After that, we might be in a position to draw some conclusions about the historical forces that have shaped the site and its people.

\section{I}

The history of Wolston Park makes sense by remembering that in the nineteenth century the impulse of government was to separate, even segregate, the insane for their own as well as the public benefit. The drive of the twentieth century, especially after World War II, was to explore ways of reintegrating the mentally ill. It is this twofold movement of separation and reintegration that makes sense of both the enormous investment in the construction of asylums and specialised hospitals and their eventual demise.

At Wolston Park, this movement of separation and reintegration can be traced through at least four major phases in the century after those first patients were admitted. These are captured in Table 1. Like any abstraction, this attempt to identify the changes over time in the defining characteristics of the hospital and its era can only be made intelligible if we colour in the detail, allowing the possibility of failure, shortcomings and misadventure, not to speak of unintended consequences. The constant reshaping of the hospital, its buildings, its staff and not least its population of patients and inmates is a story with both vitality and torpor at its heart. 
Table 1: Phases of separation and reintegration at Wolston Park

\begin{tabular}{lll}
\hline Years & Phase & Major characteristics \\
\hline $1865-1909$ & Asylum & $\begin{array}{l}\text { Institutional separation: building and } \\
\text { defining the separation of the insane }\end{array}$ \\
1909-1937 & Moral management & $\begin{array}{l}\text { The hospital as a self-contained way } \\
\text { of life }\end{array}$ \\
$1938-1962$ & Mental hygiene & $\begin{array}{l}\text { The hospital as hub of a diversity of } \\
\text { services and functions }\end{array}$ \\
& Psychiatric services & $\begin{array}{l}\text { The hospital as an element in an } \\
\text { integrated, and reintegrating, service }\end{array}$ \\
\hline
\end{tabular}

In this short space, it is not possible to paint the whole picture and give life to this abstraction in the history of the hospital, its daily routines, the lives of its staff and patients. But we can take some snapshots of the hospital at points in time when questions were asked about its past and its future. There were many points in the first hundred years when that was done - usually by force of external circumstance. Parliamentary inquiries and Royal Commissions coloured the first 50 years of the asylum, in 1867, 1869, 1877, 1880 and 1915. The focus of these inquiries was alternately on the asylum's management, its efficiency, its failings, its inadequate accommodation - or else on the perennial anxiety about patient liberties, treatment and mistreatment. In such respects, the history of Wolston Park in these decades resembled that of its companion asylums in other colonies and states - at Callan Park, Kew, Parkside or Fremantle.

At times, only its topography seemed to differentiate Wolston Park from those other places. It was, of course, a vulnerable site, subject to the impressive floods of the Brisbane River, which marked its meandering western boundary. In the 1890s, repeated flooding — sometimes twice a year — confirmed the lessons of earlier years that the original wards of the hospital would have to be abandoned. 'This Report is short and unusually delayed,' reported the superintendent in 1890, 'as in the March floods the contents of the Asylum offices were destroyed and almost all the statistics washed away or destroyed'. ${ }^{10}$ Today, the hospital sits on top of the ridge that looks over the bends of the river to the west of the site. In 1865, the natural approach was by water. The relocation brought the hospital closer to the railway line, which became for many decades the principal means of access.

Facing external scrutiny, environmental threats and constant internal disorganisation through overcrowding generated by a rapidly increasing colonial population, it is scarcely surprising that administrations in the first half century were doing little more than holding the institution together. The longest serving administrator of the nineteenth century era was Richard Battersby Scholes, from 1882 to his death while still in the post of medical superintendent in 1898. His years were dominated by makeshift arrangements in the management of a hospital population that doubled in the two decades from 1880 . 
Historians of the asylum have shown how asylum management became a specialty by the end of the nineteenth century, defining what a medical superintendent would be. While clinical discussion was never wholly absent from the annual reports or correspondence, it was subordinate during these decades to the preoccupying questions of institutional design and coordination, the management of resources, the supervision of staff and the description of the burgeoning institutional population. Some superintendents retained a faith in the possibilities of the therapeutic value of a well-shaped environment. Wolston Park had its own example in the figure of Dr H. Byam Ellerton, an English-trained specialist of the Edwardian era who was appointed to the dual post of Inspector of Asylums and Medical Superintendent of Goodna Asylum in 1909.

Ellerton's 28-year reign changed the Wolston Park site into its modern form - not only through the addition of a large number of wards that formed the core of the hospital until its recent transformation, but also through his attention to the institutional environment. There is a utopian element in the ambition and optimism of Ellerton's vision, one which sought to capture the potential of an integrated, almost self-sufficient community. ${ }^{11}$ The grounds became gardens, as Ellerton opened up the institution to visits from patients' friends and relatives; wooden fences were replaced by less claustrophobic wire, or buried in the ground as a 'ha-ha'. Mealtimes became opportunities for the social improvement and rehabilitation of patients in dining rooms that resembled Edwardian tea-rooms: tables seating four people replaced benches and mess tables; and there were pictures on the wall and potted palms on sideboards. Ellerton had a particular fondness for music as an improver of spirits and mentality, and for cricket - played on what was regarded as one of Queensland's best ovals, cleared and developed by the labour of the patients. He was particularly proud of the extraordinary 'bush-house', 100 yards long and 20 yards wide, that was constructed in 1912 at the spot near where Ellerton House was later built, and which provided flowers for the wards and seedlings for the planting of the grounds.

Ellerton's early years were marred by the hostilities and suspicions generated in the Royal Commission of 1915, an event that appears in part to have been the result of staff discontent with the style and standards of an institutional reformer. ${ }^{12}$ Ellerton expected an improvement not only in institutional amenity, but also in staff competence - under his watch, nursing training accelerated as an expectation placed on those employed to care for the insane. In the end, however, Ellerton appears to have been the last of a generation of those who had a great deal of faith in the possibilities of a grand institution as a place of humane care and possible recovery.

His replacement at Goodna, and soon to become the first Director of Mental Hygiene, was Basil Stafford. A product of the Melbourne medical school, and a medical superintendent at Ipswich Mental Hospital since 1927, Stafford was an innovator of a quite different persuasion to Ellerton. By the late 1930s, psychiatry was a well-established specialty internationally, though still in its infancy in Australia. Stafford was alert to the influence it was having on approaches to mental illness - especially through the mental hygiene movement, with its attention to 


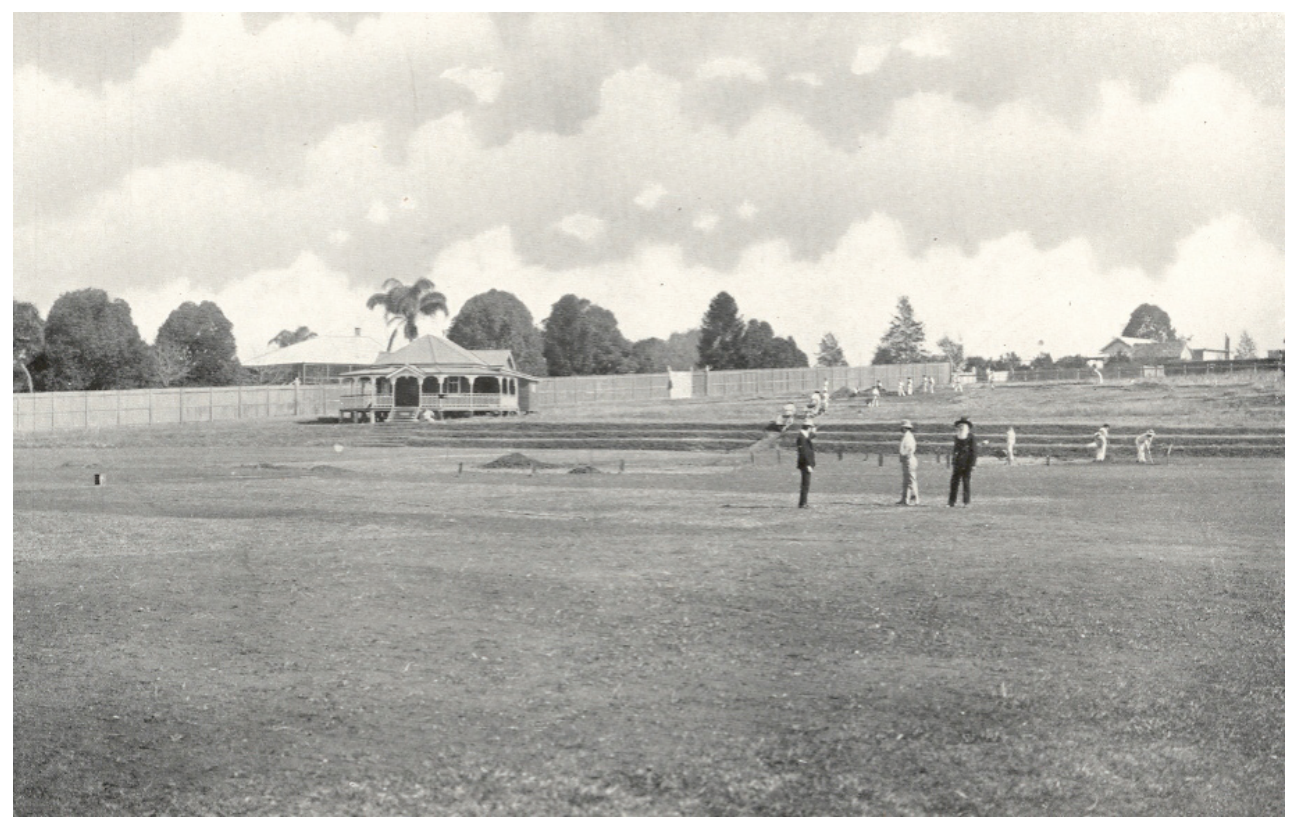

Figure 3: Occupational therapy: patients building Ellerton's cricket ground, 1911

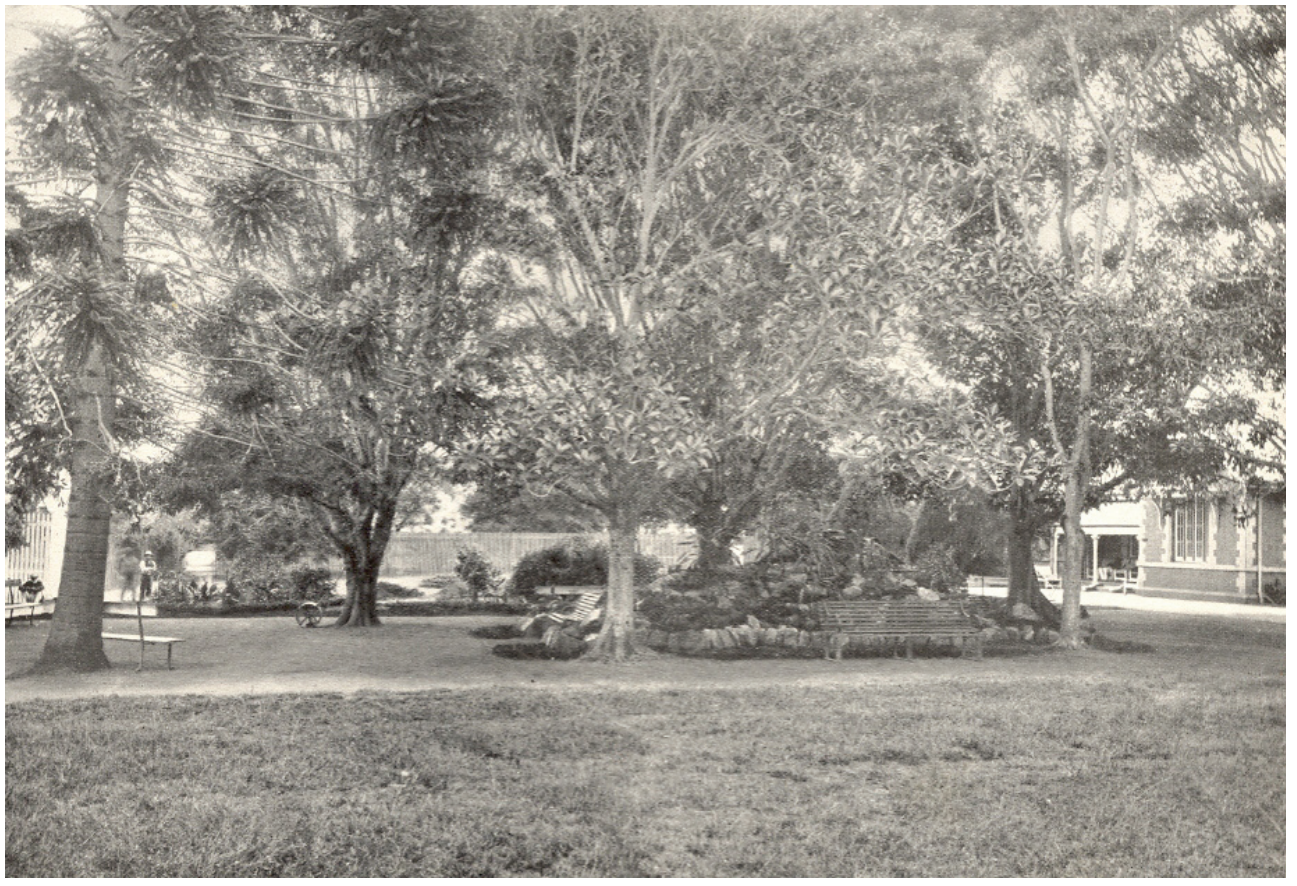

Figure 4: Moral therapy — Ellerton's gardens and rockeries at Male Ward 5, 1913 
issues of prevention and early treatment. At the outset of his appointment, he was the beneficiary also of the new attitude in Queensland public health, associated with the influence of Raphael Cilento and Abraham Fryberg in the professional domain, and a sympathetic and reforming Labor minister in Ned Hanlon. Stafford's opportunity to change the way in which Queensland approached mental illness came with approval for him to undertake a study tour in late 1937, during which he also represented the Commonwealth Government at the Second International Congress of Mental Hygiene in Paris.

This was no holiday masked as a study tour. Stafford's closely typed 40-page report on his findings was presented to the government in 1938, capturing his views on the state of psychiatry and psychiatric provision in the United States, Europe and the United Kingdom. As he told Hanlon:

I felt that, to be most productive, I should not confine my investigations to Mental Hospitals alone, but should bear in mind the possibility of reducing the numbers of patients admitted to Mental Hospitals, and of rendering more efficient treatment, thereby increasing the discharge rate and lessening the periods of hospitalisation, which immediately suggested activities outside hospital walls. ${ }^{13}$

Visiting more than 60 hospitals and psychiatric clinics, as well as a large number of universities, interviewing psychiatric administrators and attending at least three major medical conventions including the Paris event, Stafford was brought quickly to a state of critical reflection on the system in Queensland, and especially its core activity at Goodna.

The message Stafford conveyed was that 'all mental illness demands active therapy, and treatment must not become merely custodial'. Symptomatic was the English Mental Treatment Act of 1930, which had replaced the primary orientation to detention with a focus on prevention and cure, through voluntary treatment. This was to be the direction in which Queensland would move, as the Labor government proceeded almost immediately in 1938 to introduce a Mental Hygiene Bill. Its subsequent enactment ensured a change in administration and direction, consistent over time with Stafford's vision. Prior to the Mental Hygiene Act, which allowed voluntary admission, hospitals like Goodna received only certified patients (most of them under a magistrate's order) — although from the 1920s it was also possible to receive hospital treatment before certification at the mental ward established in Brisbane General Hospital. ${ }^{14}$ The transition to a less coercive framework for treatment only slowly affected the population at Goodna. In 1947, Stafford reported that only 34 of the total 570 patients admitted to what was now known as Brisbane Mental Hospital had been 'voluntary'. ${ }^{15}$ By the later stages of his career, about 20 per cent of admissions were under the voluntary provisions of the Act. ${ }^{16}$

Stafford insisted in 1938: 'In itself legislation is not a therapeutic factor in the recovery from mental illness; it establishes the possibility of treatment.' So while Queensland was labouring under ancient legislation (the old statute dated from 1884), the more vivid contrasts between the old and the new were highlighted by 
the aspirant Director of Mental Hygiene in his vision for future mental hospitals, modernised therapies, an enhancement of training requirements, the creation of new para-medical specialties and the refinement of a more distinctive approach to what was known at the time as 'mental deficiency'. ${ }^{17}$ Detailing the vision helps us to appreciate the context in which Wolston Park began to change from being the monolithic core of Queensland's provision for the mentally ill and incapacitated - and to recall the barriers that stood in the way of a wholesale transformation.

Stafford had visited some of the large American institutions, holding more than 6,000 patients, and commented on two under construction that were planned for 10,000 patients. The Goodna hospital in 1937 had a daily average population of less than 2,000 - a large institution but of a size that Stafford considered satisfactory for 'economy and efficiency in administration'. When it came to medical staffing, however, Goodna was well behind the standard expected in modern practice. 'Modern treatment' he noted, 'demands exhaustive mental and clinical case histories, as well as completely thorough physical examination. This cannot be done by a skeleton staff, however willing.' On the standards established by the London County Council hospitals, it might be expected that all mental hospitals of 2,000 or more should have ' 8 medical officers, not including the Medical Superintendent'. This was a considerable increase on the staffing of the Ellerton era, which had largely looked to improved nursing care and a congenial institutional environment.

Stafford recommended immediate appointment of an additional four medical officers, one to deal with admissions, one for a proposed neurosyphilitic unit, one for the development of new treatments, especially of schizophrenia, and one to assist in general medical services in the hospital and infirmary wards as well as to coordinate clinical and pathological work. A decade later, as the hospital's daily resident population crept past 2,000, a total of five medical officers were employed, including H.R.G. Barrett, the Deputy Medical Superintendent, all under the direction of Stafford, by then the Director of Mental Hygiene as well as Medical Superintendent. ${ }^{18}$

The medicalisation of the asylum entailed in Stafford's vision flowed from his recognition that 'psychiatric therapy is essentially individualistic treatment'. The hospital would be organised in a way that focused attention on treatment, both physical and psychotherapeutic. A corollary was the clear separation of the 'chronic' wards from those dealing with admission, convalescence and hospital cases. Stafford would persist in this strategy throughout his subsequent career, resulting by the late 1950s in the establishment of the 'Eventide' home and other facilities for the accommodation of aged and senile patients.

The development of a comprehensive psychiatric approach was also a career preoccupation, again evident in his 1938 recommendations on Goodna. Specifically, he sought the construction of a new admissions unit for both sexes, "male and female wards for intensive clinical psychiatry', as well as convalescent and infirmary wards. 'Special treatment' in the future would require the provision of adequate accommodation and facilities — including a pathological laboratory, an 


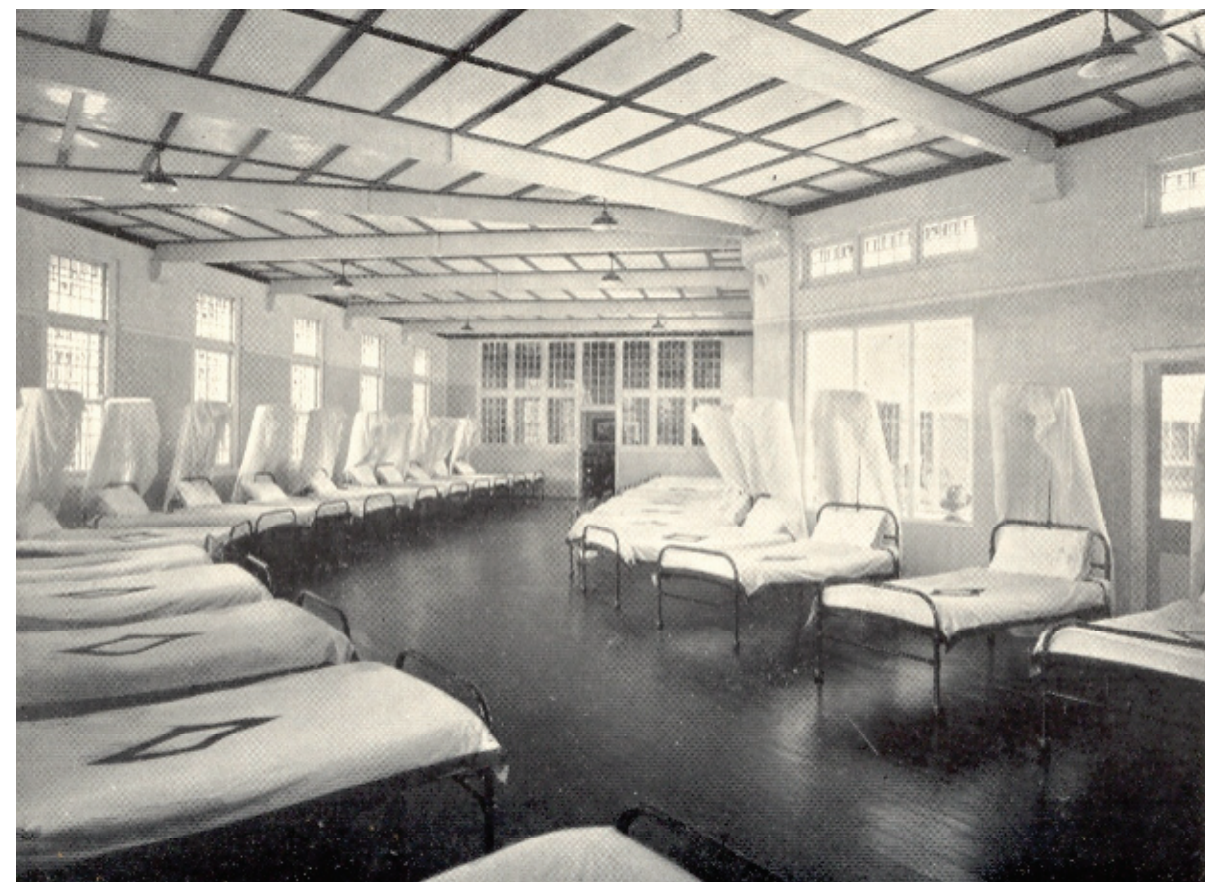

Figure 5: The mass institution — dormitory setting for a male ward, 1936

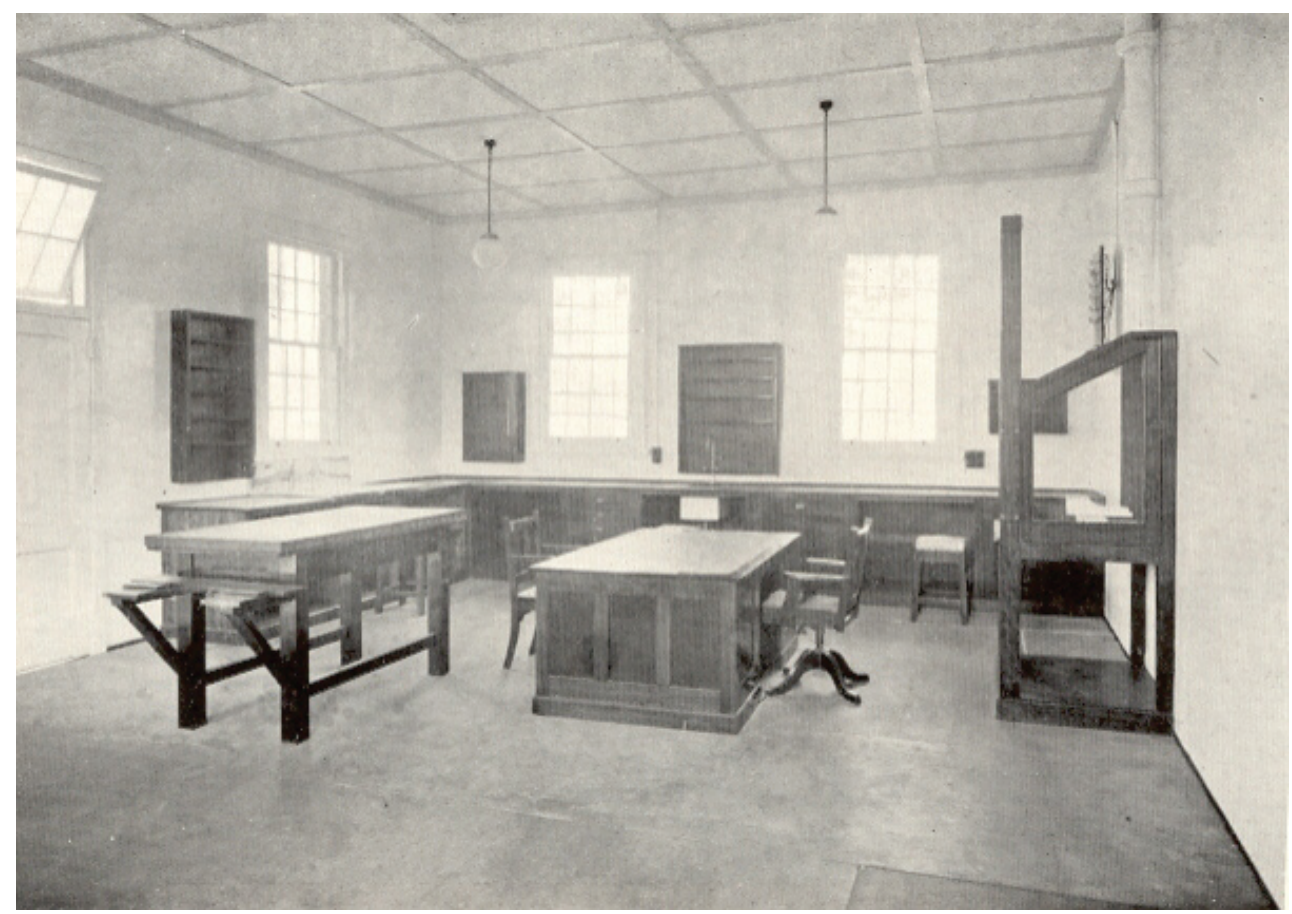

Figure 6: Vision of the future - Stafford's new pathological laboratory, 1939 
'X-ray installation' and a 'malaria and neurosyphilitic unit'. The last of these was fundamental to addressing the problem of a group of patients who made up at least 8 per cent of the Goodna population but Stafford thought it more likely to be up to 20 per cent.

Equally, special treatment facilities would be necessary if Goodna were to develop modern approaches to schizophrenia - responsible, he said, for 25-30 per cent of admissions. Stafford had met Dr Manfred Sakel in both New York and Vienna, and like others of his time was impressed with the potential of Sakel's 'insulin-shock' treatment. His evaluation of the recovery statistics was judicious and his recommendation for its use was accompanied by warnings that such invasive treatments required dedicated medical staff. 'At Goodna', however, 'the medical staff [establishment] is so poor that it is impossible for a Medical Officer to devote his whole attention to six patients, which means that it is not possible to successfully carry out this treatment until additional Medical Officers have been appointed.' Similarly, the introduction of another experimental treatment of that era, the administration of the drug Cardiazol to induce an epileptic type of seizure in schizophrenic patients, could not be contemplated unless medical staffing at Goodna was improved. Such drastic interventions could not in any case work on their own - after-care was crucial to sustaining recovery with 'studied dietetic, occupational and recreational therapies adapted to each individual patient ... continued attention must be given to the patient if he is to remain reclaimed from his realm of introverted fantasy and returned to the community as an effective social unit'. ${ }^{19}$

While Stafford refrained from specific comment on the Ellerton regime at Goodna, his report demarcated a boundary between a modern future, in which individualised treatment would be based on intensive clinical investigation, and a stagnant past, in which the hospital had functioned as not much more than the institutional expression of a legalised detention regime. There is some substance to this view. Ellerton had brought with him from England the expectations of a Victorian and Edwardian asylum system that elevated institutional architecture and regime over effective therapy — a system that has been characterised as 'moral management' in place of the older 'moral therapy'. ${ }^{20}$ Ellerton had presided over not only a growth in resident numbers but a great expansion in the hospital's facilities and a refinement of its amenity. His standard was the appearance of things - he was an institutional builder who saw in the evidence of an expanded physical domain a confirmation of his own integrity of purpose. One of his last reports, in 1936, contains a fine topographical depiction of the hospital site, with the asylum buildings coloured according to their age, before or after 1909 (the year of his arrival). His reports continued the preoccupations of an older era, focusing on the social characteristics of patients, and the details of asylum management.

In contrast, Stafford's reports would become briefer, and more concerned with the forms of mental illness - and with the coordination of administrative reform consistent with his vision of the renamed 'Brisbane Mental Hospital' as a centre for the treatment of illness rather than the accommodation of the chronically ill and the senile. A further dimension of the contrast arose from Ellerton's typically 
Victorian administration with the Medical Superintendent having oversight of the entire asylum operation. Stafford saw such a structure as a distraction from the clinical focus that should characterise the work of the Medical Superintendent. In its place, he preferred a model of delegation - with the administrative side of the hospital's operation overseen by a 'Steward' and an Assistant Medical Superintendent overseeing the clinical work, including the medical and nursing staff. ${ }^{21}$

Stafford's vision of the future went well beyond his address to medical staff and their role in treatment. Sharing with Ellerton a commitment to the quality of nursing, Stafford had paid a great deal of attention on his study tour to the requirements of a qualified nursing staff. Ellerton certainly had recognised this as a core requirement, and during his time the proportion of staff with general as well as mental nursing certificates increased rapidly. He instituted a certificate of mental nursing at Goodna in 1912. Predictably, it was not warmly embraced by some of the longer term staff, who made their feelings known at the 1915 Royal Commission. Male attendant Joseph Mulkerin, for example, who had been 22 years at Goodna, spoke bitterly about the mental nursing manual, the 'Red Book ... this Psychological Book' (the Handbook for Mental Nurses, published by the British Medico-Psychological Association since 1885, was bound in a red cloth cover), which he saw an emblem of what was wrong with Ellerton's regime:

I don't think a psychological Red Book is required to look after bugs. I don't think an attendant is trained - I think an attendant is born. I remember the great humane Dr Hogg saying that. I think he is more born than trained.

Old hands like Mulkerin criticised the system for promoting men who passed exams:

Is it right that a man who goes to a technical college and learns the theory of a thing should be put above a man with a long practical experience? ?2 $^{2}$

In spite of such criticism, Ellerton persisted, and his reports trace the gradual credentialisation of mental nursing in Queensland. By 1931, over 80 per cent of the male and 65 per cent of the female nurses were state-registered mental nurses who had passed the mental nursing examination conducted by the state Nurses' Registration Board.

While acknowledging this achievement, Stafford was in 1938 critical of the quality of nursing, the service 'attracting on the whole an inferior type of applicant; the person who through insufficient natural ability or primary education was unable to make a success of other employments'. Encouraging a better applicant through improved pay and a higher education standard (the base entry required only fifth grade primary school education) was just the start in achieving a better nursing service. The selection of applicants was too subjective, vulnerable to "political patronage': preference had been given to returned soldiers and married men, while the age requirement of 21 years for female nurses restricted the pool of applicants. 
Promotion by seniority detracted from quality. Stafford wanted to see 'efficiency', broadly defined, and he had been impressed by the systems of 'staff rating' he observed in New York and Massachusetts. Again, one is struck by the degree of Stafford's knowledge of the techniques of the modern clinician and manager.

The standard of training itself he regarded positively, but better teaching facilities were needed, 'such as good models and charts, suitable lecture theatre, amphitheatre accommodation in the mortuary, and a slightly increased staff so that more time could be given to instruction of trainees in the wards'. His expectations of the future were evident in Stafford's insistence on the status of nursing work, which he claimed was undermined by requirements that nurses do maintenance and manual work. 'Their duty,' he affirmed, 'should be primarily to skilfully attend to the mental and physical needs of the patient.' In this respect, a further signal of the future of Goodna as a hospital rather than a detention centre was Stafford's recommendation that 'attendants be called male nurses, and be provided with uniform suggesting medical and nursing attention and not suggesting a jail or prison atmosphere'. ${ }^{23}$ Stafford's vision for a qualified and well-remunerated nursing staff would be constantly challenged by the realities of acute labour shortages (especially of female nurses), a problem he shared with directors in other states. ${ }^{24}$

Through both legislative provision for improved training (under the Mental Hygiene Act 1938) and the improvement of accommodation and training facilities at Wolston Park, Stafford pursued this agenda in the following decades. ${ }^{25}$ Yet, in spite of the important conceptual shift towards a non-institutional and psychiatric frame of reference, the realities of asylum administration were never too far away. In August 1945, Stafford wanted eight cells in the Female Ward 8 condemned, as they were not fit for human occupation, or else renovated by knocking out a large window in the back of the building and putting wooden floors down. Accommodation was so pressing that there was no alternative to the measure: a departmental memo recommended the work be done, as it 'might prevent newspaper comment at some future date'. ${ }^{26}$

The papers were never far away. In April 1949, Stafford was forced into a furious public defence of Goodna and his own administration after the CourierMail backed calls for investigation into ill-treatment at the hospital. Apart from the 'persistent calumny directed against the nursing staff of our Mental Hospitals', what incensed Stafford was the paper's suggestion that Queensland should invite a senior New South Wales official to report on the state's mental hospitals. 'We are not perfect,' Stafford riposted, 'and we have a good deal to improve. The war stopped the fulfilment of the plan I made 10 years ago, but we are still ahead of what NSW ought to do. We are at it all the time.' The new hospital at Charters Towers was on the way, and there were plans for a 200-bed neuro-psychiatric hospital at Indooroopilly. ${ }^{27}$ Charters Towers would be finished, but the Indooroopilly venture never proceeded. It would be more than another decade before Stafford could welcome the government's commitment to the alternative - the psychiatric facilities at Chermside. A loyal public servant, his official reports do not convey the difficulties faced in moving Queensland's major mental health facility in the direction he wished. In a major review of Australian mental health needs in 1955, 
Alan Stoller found the Director's planning sound, but saw little at Wolston Park that would qualify its inclusion in the overall judgement that Australia's 'mental hospitals are hopelessly overcrowded, poorly maintained and short-staffed, and, as a result are confined to little beyond a custodial role'. ${ }^{28}$ As always, it was one thing to paint a vision of the future, another to obtain the commitment of government support and resources to carry it through.

\section{II}

The hospital hosted well over 50,000 patients in the 120 years from 1865 to the mid-1980s, by which time the notion of a single hospital unit was already well past. The growth of the hospital population was continuous from the 1860 s to the 1950 s, after which a long decline spoke of the increasing impact of diversification of services, new treatment regimes (especially through the availability of psychotherapeutic drugs) and the policy of deinstitutionalisation. The population data in Figure 7 reflect both the reality of Queensland's population growth over time and the distinctive nature of provision (and default of it) for the mentally ill over time.

The extent to which Wolston Park mirrored the history of Queensland, as well as the changing history of mental health policy and psychiatric practice, is evident when we trace some of the population characteristics over time. Where did the patients come from, and what happened to them? We cannot tell their stories in this short space but some figures help to sketch the picture.

This institution at the southern end of the state remained for a century the central facility for those who needed long-term custody or care, or who were

Daily resident population, Wolston Park Hospital, 1879-1989

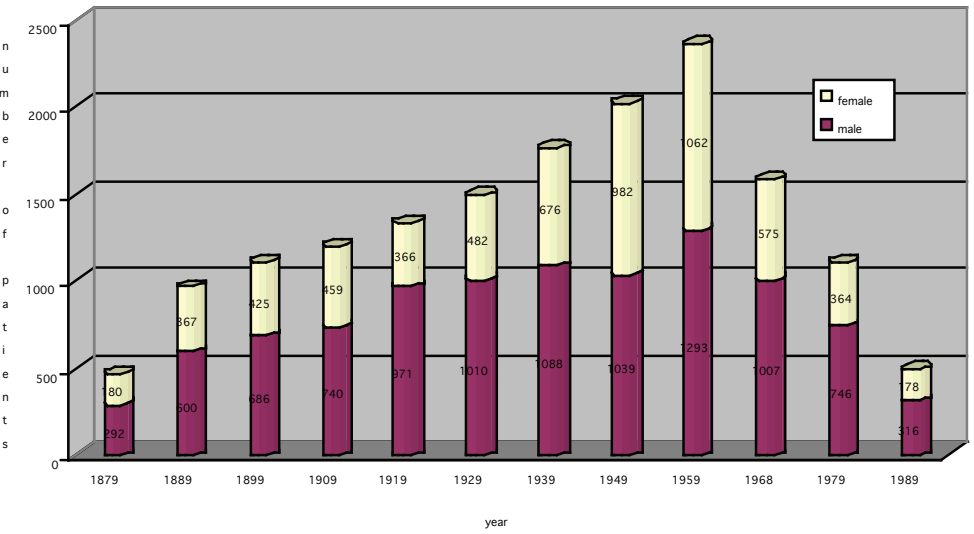

Figure 7: Daily resident population, Wolston Park Hospital, 1879-89 
simply forgotten. The statistics tell the story: people travelled - or rather were escorted - over great distances, by rail mainly, to be admitted to Woogaroo or Goodna. We can gauge the proportions from the reports of the districts of origin, as evident in the figures shown in Table 2.

Table 2: District of origin of patients admitted to Wolston Park (\%)

\begin{tabular}{lrrrr}
\hline & 1901 & 1931 & 1951 & 1961 \\
\hline Northern & 18 & 20 & 10 & 5 \\
Central & 22 & 11 & 8 & 5 \\
Southern & 60 & 68 & 82 & 91 \\
$\mathrm{~N}=$ & 335 & 372 & 760 & 947 \\
\hline
\end{tabular}

As the data in Table 2 suggest, over time Wolston Park received more of its patients from its immediate region. To a degree, these changing proportions reflected the changing demography of Queensland, but they also point to the reality that by the 1960 s there was a major facility in north Queensland. It was not before time. The urgent need for an appropriate mental hospital had been a live issue since the late nineteenth century, yet another grievance of those who lived at a distance from the metropolitan south-east. Recognising the hardship of families whose relatives were hospitalised at Wolston Park, the Labor government in the interwar years provided free rail passes to enable needy families to visit their relatives at the hospital.

The hospital's statewide catchment represented a hardship to the patients from remote districts as well as to their families. The stigma historically attached to mental illness is captured in the smallest ways - in this case, in the very means of transporting the insane. From the 1920s to the 1950s, the transportation of patients to Wolston Park was by rail: for many years in what was called the 'leper van' because it was also designed to convey those suffering from Hansen's disease (leprosy), as well as prisoners. The superintendents of the hospital struggled for years with a generally hostile Railways Department to ensure that the mode of conveying mental patients would not worsen their condition, physically as well as mentally. Concerned with the sensibilities of other passengers, the railways commonly attached the 'leper van' to the Townsville goods train, rather than the faster and more comfortable passenger train. At Brisbane, they were conveyed to the asylum in the prison 'Black Maria', a practice to which Ellerton strongly objected, and eventually altered by the use of an ambulance. ${ }^{29}$

A different problem was created by the discharge of patients. While the 'recovered' or 'relieved' living in the Brisbane region may have had secure housing destinations and immediate assistance in getting there, the plight of others in the days before social workers and welfare pensions was unenviable. The problem was not insignificant, especially when we identify the large numbers who were 
discharged from the hospital every year. Whatever the reputation of the hospital as a custodial institution, the reality was that in every year there was a high turnover of the population, with hundreds being discharged. The other reality of the hospital's place as a destination for the very sick or the very old is highlighted by Ellerton's summary of the aggregate statistics from the 1860 s to 1930 . Of the nearly 20,000 patients admitted to that date in the state's mental hospitals, nearly 35 per cent had died there, over 48 per cent had been discharged 'recovered' or 'relieved', and nearly 16 per cent remained in the state's hospitals - most of them at Wolston Park.

The very large number of deaths recorded in these statistics suggests a persistent reality of Wolston Park's history from its earliest days up to the 1950s. For these figures are not just the consequence of a higher mortality risk of the mentally ill, or (as was sometimes alleged, often feared, and with some justification) of mistreatment and lack of care, but of the functioning of the asylum as, in effect, a hospice. Wolston Park was often the end point for people who were already very ill, and who were likely to die within a relatively short period after admission to the hospital. The asylum of the nineteenth century, and the mental hospital after it, were not intended to function as hospices for the dying, or depots for the senile and abandoned aged. But in an era when there were few other options for residential care for the physically as well as mentally ill, the mental hospital was the final resting place for many. We can see the impact of this reality by examining some mortality data at slices of time in Table 3 .

Table 3: Mortality in Wolston Park Hospital, selected years

\begin{tabular}{llllc}
\hline & & \multicolumn{2}{c}{$\begin{array}{c}\text { Proportion of those who died } \\
\text { after less than twelve months } \\
\text { in hospital }\end{array}$} \\
\hline & Male & Female & Male & Female \\
\cline { 2 - 5 } 1879 & 24.1 & 26.1 & 42.9 & 41.7 \\
1929 & 44.3 & 36.0 & 43.0 & 51.2 \\
1969 & 23.2 & 22.2 & 61.9 & 52.7 \\
\hline
\end{tabular}

These characteristics of the patient population, and its rates of discharge or death at the hospital, are part of a very complex history of quite different patient experiences of the hospital. The reality for very many was a relatively short stay at the hospital, while for others admission was the beginning (or even a continuation) of a lifetime in institutions. In the late 1930s, Stafford had defined a future in which mental hygiene services would attune more finely the design of institutions to the needs of particular patient populations. By the mid-1950s, however, the Brisbane Mental Hospital was described by Alan Stoller as 'an admission institution, a chronic mental hospital, a centre for adult mental defectives, and an inebriates' institution'. This was not to count its special repatriation pavilion, funded by the 
Commonwealth, on the same site. It was in fact the largest single mental hospital in Australia, with about 2,500 daily average residents, even though total mental hospital inmates in Queensland were only a third of those in New South Wales, and half of those in Victoria.

Stoller visited Wolston Park at the peak of its institutional history as a largescale facility. By the early 1970s, the numbers being cared for on a daily basis had halved, and by the mid-1980s there were fewer than 600 beds occupied at the hospital. The changes were a result of changing policy, as the new regime of psychiatric services devolved care of the mentally ill into a wide range of community clinics and psychiatric wards in general hospitals. The critiques of the custodial mental hospital that developed from the late 1960s came in the wake of a change that had already swept through the institutions. The altered climate was already described by the new Director of Psychiatric Services, Gordon Urquhart, in a reflective report in 1968 . The 25 per cent decline in patient populations since the peak of 1956 was accounted for in part by the decline in the numbers of chronic geriatric patients as a result of their discharge into other facilities; and otherwise by falling admissions, better treatment and early discharge. Very important was the impact of early treatment at general hospitals, which Urquhart claimed treated more than 80 per cent of psychiatric patients in the first instance.

The Chermside Unit had contributed largely to the decline in the number of admissions, while other special facilities were being created around the state. ${ }^{30}$ Further changes were evident in the higher rates of early discharge, with those discharged in

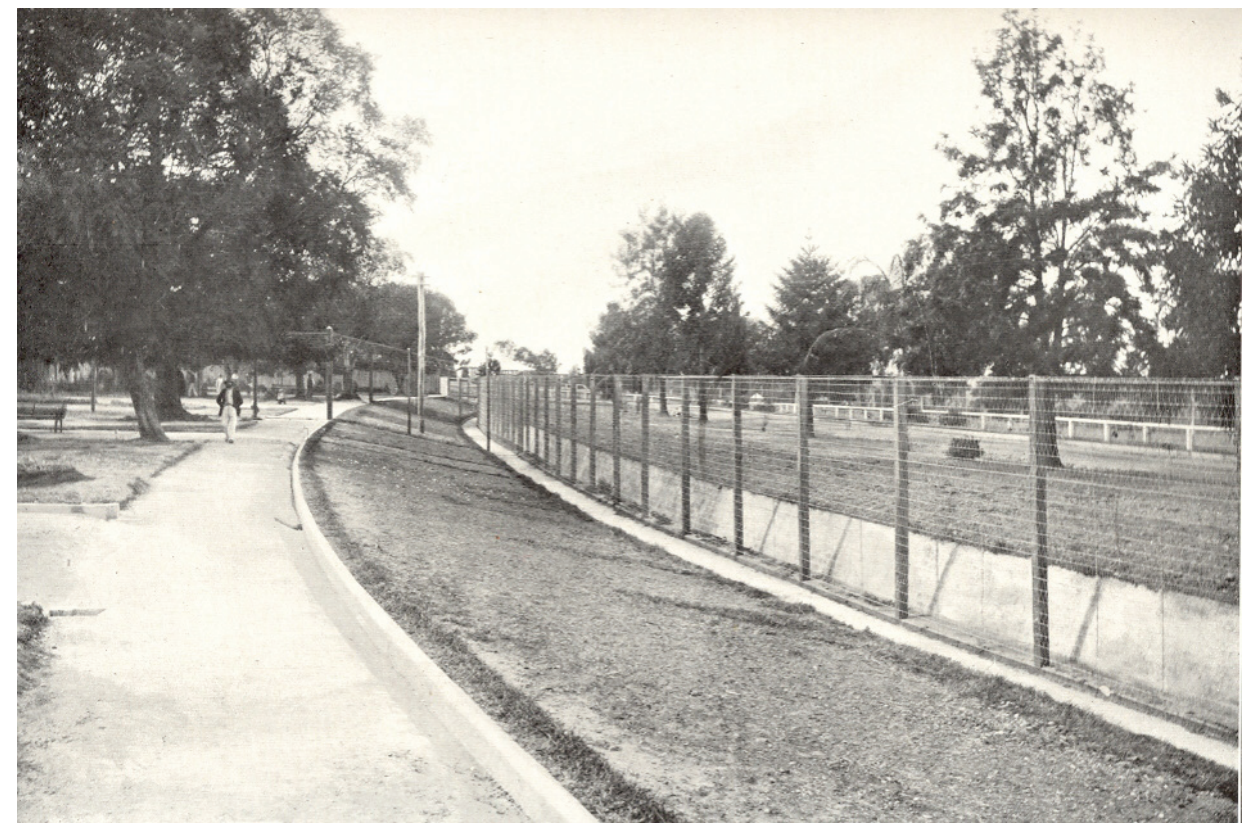

Figure 8: The dilemma of the asylum — the sunken fence, 1917 
less than twelve months from admission increasing from 50 per cent in 1957 to over 77 per cent a decade later, and in the decline of compulsory detention as more use was made of voluntary admission procedures, a change assisted by the new provisions of the 1962 Mental Health Act.

\section{III}

The conditions that gave birth to the lunatic asylum at Woogaroo have long since passed, and so too have those that shaped the successor institutions down to Wolston Park Hospital and the most recent innovation, The Park Centre for Mental Health. Those conditions included a recognition that the behaviour of some people was of a kind more likely to be remedied by special care and treatment than by punishment. But there was another impulse, one driven by a fear of the dangerous person who had not yet committed a crime but whose imprisonment was justified by their threat to society. Both impulses marked the history of the asylum from the beginning. It was first an institution of segregation, at a time when a medical and nursing practice had not yet developed that could justify its naming as a hospital. Over time, those professions developed a kind of knowledge and practice that shaped an institution that looked more like a hospital, and so there emerged places like Goodna Hospital for the Insane and, later, Brisbane Mental Hospital. The hospital's population, however, as much as medical direction would have wished to avoid such a conclusion, was of such diversity that it functioned almost as much as a hospice for the dying as for the recovery of the mentally ill, while there was also a regular proportion whose condition was such that their lives became identical to that of the hospital.

The changes that brought Wolston Park Hospital into being in the late 1960s were also those that brought it to an end in 2001. These included a rapid growth in medical knowledge and treatments in the postwar era, a diversification of treatment modalities, a profound alteration in the legal regulation of mental illness shifting from a community protection rationale to a presumption of a right to treatment, and the proliferation of social security and health insurance provisions that offered a quite different set of possibilities for the support of the mentally ill. Predictably, these changes have not always brought with them any guarantee of security and care for the mentally ill, nor adequate provision for their treatment.

For there are also many continuities. Media sensations about the dangers of escaped lunatics sit side by side with more reflective commentary on the realities of a mental health system that continues to face a shortage of resources and staffing and therefore cannot ensure adequate care for all those requiring it. New mental health legislation and a major new mental health care facility signal a renewed commitment to the protection, care and treatment of the mentally ill. These are all things that are familiar from the history of Wolston Park, and indeed from the history of mental health provision generally in Australia as elsewhere. In addressing what are today regarded as pressing national as much as local issues in mental health care, we have much to learn from those histories about the kinds of 
commitment required from government, the community and its civic institutions, as well as from those engaged in the mental health services themselves.

\section{Acknowledgement}

This article is a revised version of an earlier account published privately on the occasion of the closing of the Wolston Park Hospital in 2002. It draws on historical research originally conducted for a collaborative project between Griffith University and Queensland Health, West Moreton Health Service District, with funding support from the Australian Research Council. Special thanks are due to Jonathan Richards, Margaret de Nooyer, Terry Steadman, Kevin Fjeldsoe and Nadia Beer for their support, ideas and feedback at various stages of the project. The views expressed in this publication are those of the author alone.

\section{Note on Illustrations}

The pictorial images are all taken from the Annual Reports or reports of official inquiries. The chart and tables have been prepared from data in the Annual Reports for the relevant years.

\section{Notes}

1 Annual Report, 1935-36, 51.

2 Brisbane Courier, 9 February 1864; Queensland Legislative Assembly Papers, 1867, 'Lunatic Asylum Woogaroo', 22.

3 For other accounts of the development of the asylum and hospital, see R. Evans, Charitable Institutions of the Queensland Government to 1919, Brisbane, unpublished MA thesis, University of Queensland, 1969; Queensland Heritage Register, 'Wolston Park Hospital Complex', 2006, retrieved 18 December 2007 from www.epa.qld.gov.au/projects/heritage/index. cgi?place $=600340 \&$ back $=1$.

4 Circular from Secretary of State for Colonies, 14 January 1864 - 'Colonial Hospitals and Lunatic Asylums' EXE/E10, 64/37, Queensland State Archives (QSA).

5 Executive Council Minute 13 August 1864, EXE/E10, 64/37, QSA.

6 For a detailed account of the history of the site and its buildings, see Queensland Heritage Register, 'Wolston Park Hospital Complex'.

7 Queensland Parliamentary Debates, 14 October 1938, 941 (Mr Maher, MLA, West Moreton).

8 Queensland State Archives (QSA), EXE/E 10, Executive Council minute, 13 August 1864.

9 There is now a large international literature on the history of the asylum. For Australia, see especially Evans, Charitable Institutions of the Queensland Government; S. Garton, Medicine and Madness: A Social History of Insanity in New South Wales 1880-1940 (Sydney: UNSW Press, 1988); M.J. Lewis, Managing Madness: Psychiatry and Society in Australia 1788-1980 (Canberra: Australian Government Publishing Service, 1988); C. Coleborne, Reading 'Madness': Gender and Difference in the Colonial Asylum in Victoria, Australia, 1848-1880 (Perth: Network Books, 2007). For a recent collection of international studies, see D. Wright and R. Porter, The Confinement of the Insane: International Perspectives, 1800-1965 (Cambridge, Cambridge University Press, 2003).

10 Annual Report, 1889, 1. The Annual Reports were published in the Parliamentary Papers of Queensland - their titles vary over the years. 
11 See also M. Finnane, 'The Ruly and the Unruly: The Uses of Isolation in the Management of the Insane', in Isolation: Places and Practices of Exclusion, eds A. Bashford and C. Strange (London: Routledge, 2003), 89-103.

12 For a different view, emphasising the continuity of public neglect and institutional ill-treatment, see R. Evans, 'Flickering Insights: The Press, the State and the Asylum and Goodna Mental Hospital, Queensland, 1915', in Madness in Australia: Histories, Heritage and the Asylum, eds C. Coleborne and D. MacKinnon (St Lucia: University of Queensland Press, 2003), 97-108.

13 A/31781, February 1938, QSA.

14 See Annual Reports, 1908, 2; 1930-31, 7.

15 Annual Report, 1946-47, 88.

16 Annual Report, 1960-61, Table LXX.

17 See E. Cocks, Under Blue Skies: The Social Construction of Intellectual Disability in Western Australia (Joondalup, WA: Centre for Disability Research and Development, Faculty of Health and Human Services, Edith Cowan University, 1996); D. Wright, From Idiocy to Mental Deficiency: Historical Perspectives on People with Learning Disabilities (London: Routledge, 1996).

18 A/31781, 13, 40, QSA; Annual Report, 1948-49, 94.

$19 \mathrm{~A} / 31781,26$, QSA.

20 A transition noted by many historians of the era - see, for example, Andrew Scull, The Most Solitary of Afflictions: Madness and Society in Britain, 1700-1900 (London, 1993), Ch. 6; Stephen Garton, Medicine and Madness: A Social History of Insanity in New South Wales, 1880-1940 (Sydney: UNSW Press, 1988), Ch. 8.

$21 \mathrm{~A} / 31781,14$, QSA.

22 Royal Commission of Inquiry into the Management of the Hospital for the Insane, Goodna, 1915, Evidence, qns. 15975, 16082

23 A/31781, 37, QSA.

24 See Annual Report, 1950-51, 70.

25 For example, Annual Report 1944-45, 41-42.

26 A/31932/45/11768, 27 August 1945, QSA.

27 Courier-Mail, 30 May 1949; Courier-Mail, 27 May and 9 April give the background.

28 Alan Stoller, Report on Mental Health Facilities and Needs of Australia, Canberra, 1955, 111, 167.

29 QSA, A/31782.

30 Annual Report, 1967-68, 43-44. 